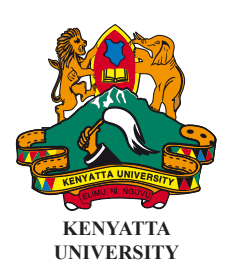

ISSN 1563-1028
CHEMCHEMI

International Journal of Humanities and Social Sciences

\title{
DEVELOPMENTAL CHANGE AND PEACE AMONG CHILDREN IN KENYA
}

\author{
Pamela M. Y. Ngugi
}

\begin{abstract}
The concept of engaging children all over the world in participation or consultation is a relatively recent advent within the children's right arena, and at least at first glance is an idea alive with promises and potential. This promise has special significance, given the range of conditions in Kenya that render most of the children particularly vulnerable. Thus children have been given a platform through the Children's Assembly, through which they can engage with the many unique problems that curve out their daily existence. It is in this regard that the paper argues that given an opportunity children can be agents of peace, change and development in their own right. The paper presents information from the children's themselves concerning their present experiences and future aspiration by examining the functions of the Children's Assembly, Kenya and how the assembly engages children in contributing in meaningful ways to discussions of issues affecting them. By so doing, they are considered as agents of change, peace and development in relation to their engagement in the educational process, access to and negotiation of work, development of survival strategies in extreme conditions of poverty and deprivation that affects most of the children in Kenya.
\end{abstract}

Key words: Children, rights, participation, peace, assembly

\section{Introduction}

The concept of children's participation and inclusion in society has been heightened in national and international policy agenda in different countries of late (Mokwena, 2003). This new concept of childhood in which children are regarded as social actors rather than passive beings on their way to adulthood has gained a lot of popularity. The new perspective requires child - focused development organizations fundamentally to reassess their assumptions and rethink their approaches. The aim of these efforts has been to improve the understanding of children's lives, their interest, capacities and needs (Theis 1998: 81). Boyden and Ennew (1997:39) provide some definition to the concept of children's active participation. They state that child participation:

\section{... should mean children are at least informed about and consulted in actions taken for their welfare, and may be involved in planning, implementation and evaluating these actions.}

McNeill (1998:31) points out clearly that participation should not be seen as a token involvement of children but how to incorporate their specific needs and views into decision- making process within the context of what is possible institutionally and culturally. Children's participation therefore, is seen as a process of child development that provides an opportunity for children to be involved in decision making on matters that affect their lives and to express their views in accordance with their evolving capacity. Child participation recognizes that children are not a powerless target group, but rather capable communicators, who can effectively engage in decision-making in their own lives - within their families, schools, in respect 
of their own healthcare, in courts, in local communities, and in political forum, (Lansdown 2005:57; James \& Prout 1997:1). Therefore the new focus on children places considerable emphasis upon children as 'beings' rather than 'becoming' and that children's lives need to be studied in the here and now, rather than in terms of what they may or may not become in the future (Ofosi-Kusi 2011:3). It is in this regard that the paper argues that given an opportunity children can be agents of peace, change and development in their own right. The paper presents information from the children's themselves concerning their present experiences and future aspiration by examining the functions of the Children's Assembly, Kenya and how the assembly engages children in contributing in meaningful ways to discussions of issues affecting them. By so doing, they are considered as social actors in relation to their engagement in the educational process, access to and negotiation of work, development of survival strategies in extreme conditions of poverty and deprivation

\section{An account of the Children's Assembly in Kenya}

In 1990 , Kenya became the $20^{\text {th }}$ country to deposit her instruments of ratification with the UN General Assembly, thus enabling the Convention on the Rights of the Child (CRC) to come to force (The Hansard 2001). The CRC programs operated under the Ministry of Gender, Children and Social Development (Government of Kenya). The Department of Children's Services currently draws its mandate from the Children Act 2001 and now the Constitution of Kenya of 2010, under Children's Act, Article 53. This is an Act of parliament that makes provision for parental responsibility, fostering, adoption, custody, maintenance, guardianship, care and protection of children. It also makes provision for the administration of children's institutions, gives effect to the principle of the CRC and other related purposes. It provides for leadership in co-ordination, supervision and provision of services towards promoting the rights and welfare of all children in Kenya. It is the children's officers in this Ministry who organize and oversee the election of the various categories of members of the Assembly such as the Governor, Deputy Governor, Speaker and delegates at various stages of representation.

The Department of Children's Services has come up with operational guidelines as a strategy that enhances the Children's Assembly to reach all children, even the most marginalized groups of children, by involving them in public debates, networking and skills development at local and national levels (Department of Children's Services 2011). The specific objectives of the Children Assembly include:

- Empowering children with knowledge and skills on children rights and responsibilities.

- Involving children in policy formulation, planning, implementation, monitoring and evaluation.

- Providing a forum to promote children's participation in local, national and international events.

- Facilitating networking among children and other relevant organizations and institutions.

- Promoting nationhood among Kenyan children.

The leadership structure of the Children's Assembly is modeled on the Kenyan constitution of 2010 structure with a decentralized system of governance that is represented by counties in the country. Based on this structure, there is the County Children's Assembly, the Regional Children's Assembly and the National Children's Assembly. To come up with the national delegates, several stages of selection are followed until the group has reached the required number that is agreeable to all. This is done so as to ensure a balanced representation. The assembly meets once in a year during school holidays and the leadership has a rotational period of two years.

\section{Children and Agency}

One important consequence of the focus on active participation of children has been a growing concern with the agency of children since it is an acknowledged fact that children have agency and are socially competent beings. Giddens (1984:9 cited in Honwana 2005: 48) considers agency to be the capability of doing something rather than the intention of doing something. In essence, agency concerns events of which an individual is the perpetrator, in the sense that, that individual could at any phase in a given sequence of conduct, have acted differently. Whatever happened would not have happened if that 
individual had not intervened since agency implies a transformative capacity to intervene or refrain from intervention (Honwana 2005:48).

In that sense then, Honwana (ibid) points out that agency is intrinsically connected to power. To be able to act otherwise, the individual must be able to exercise some sort of power. This means that a person has the ability to act on their own behalf and also to influence others out of their own volitions. According to Ofosi-Kusi (2011:5), agency variously evokes personal will, ability, capacity, drive, motivation, choice, innovation, creativity, resourcefulness and action in the social agent. Children's agency therefore refers to their capacity to help shape the circumstances in which they live. Children for example, successfully claim agency within the contours of the family (Jans 2004: 28). This is what du Bois - Raymond (2001 cited in Jans 2004:28) speaks of as 'negotiation' families. This aspect is also reflected outside the sphere of the influence of the family where children grasp the opportunity to show themselves as individuals. Children's agency is a key contributor to their development hence a way of building peace in the community.

Promoting children's agency and social interaction requires their self-expression to be facilitated in their interaction with adults. In view of this then, young persons must be given the opportunity to learn through participating in decision making that affect their lives and through performing significant services that affect others. Expression of views is not restricted to formal language only, but also through emotions, drawing, painting, singing and drama.

It is in reaction to this new perspective on childhood that Children's Assembly was created in Kenya as a way of facilitating children and young people's social participation. This space gives children an opportunity to become more assertive in advocating for their rights and articulating their issues to the rest of the community. Mukasa and Grift-Wanyoto (1998: 280) advise that if properly handled and facilitated at their own pace, children open up to new ideas and contribute to the fulfillment of their rights and responsibilities as embedded in the UNCRC, the African Charter and the Children's Acts of respective countries. Through this platform, children are seen as agents of peace in their various communities.

\section{Discourses on Children's Participation in Development}

Hart (1992:5) describes the term 'participation' as the process of sharing decisions which affect one's life and the life of the community in which one lives. It is the means by which a democracy is built and it is a standard against which democracies should be measured. He goes on to say that participation is the fundamental right of citizenship. According to Henk van Beers (1995: cited in Smith 1998) participation of children should mean a radical change in the approach towards children. It means taking children seriously, trying to look at things from their perspective and treating them as subjects in, instead of objects of, research and intervention. It requires information sharing and dialogue between children and adults, which is based on mutual respect and power sharing. Genuine participation gives children the power to shape both the process and outcome.

As rightly observed by Hart (1992:6) there are a multitude of examples of children who organize themselves successfully without adult help. For instance most adults can probably remember building a play house with friends at seven or eight years of age, unknown to adults, or perhaps selling refreshments from a small stand in front of their home. Such examples from adult's memory are the most powerful evidence of young people's competence. The principle behind such involvement is motivation; young people can design and manage complex projects together if they feel some sense of ownership in them. If young people do not at least partially design the goals of the project themselves, they are unlikely to demonstrate the great competence they possess. Involvement fosters motivation, which fosters competence, which in turn fosters motivation for further projects. Young people's community participation is a complex issue which varies not only with a child's developing motivations and capacities, but also according to the particular family and cultural context. In cultures where adults themselves have little opportunity to influence community decisions, young people can become the initiating force for change, peace and development. 
There are various perspectives on participation of children that have been suggested. For example, participation in international development is suggested by White and Choudhury (2010). According to them, various arguments put forward for participation of children in international development Centre on efficiency, efficacy and justice. Efficiency requires the involvement of beneficiaries in order for appropriate and sustainable projects to be designed. The second is efficacy, that when children speak for themselves in national and international meetings, the impact is much greater than if the same arguments were made by an adult on their behalf. Thus the most effective preparation for a sense of self-efficacy is to achieve a goal for oneself and not merely to observe someone else achieving that goal. The third is justice: that people have a right to speak on and to be represented in matters concerning them as stipulated in UNCRC Article (12).

Other useful typologies have been developed to help in recognizing the way in which participation is a process rather than a product. For example, Sherry Arnstein's 1969 ladder of citizen participation has been taken up and adopted by others such as Hubley (1993) and Hart (1992). Hart (1992) draws on Arnstein's well-known 1969 conceptualization to create a child-specific ladder. He points out that in order for a project to be truly labeled as participatory, it must adhere to the following four requirements: first, the children understand the intentions of the project, second, they know who made the decisions concerning their involvement and why they were made, third, they have a meaningful rather than a 'decorative role' and fourth they volunteer for the project after it has been clarified to them. Hart (1992) suggests various levels of participation for children and how children can be and are involved. Similarly, Boyden and Ennew (1997:11) suggest that in order for the children to participate meaningfully, they need information about the reasons and consequences of what they are doing.

\section{Research Methodology}

In taking account of children's views in research, a variety of methods such as ethnography, participant observation, interviews, focus groups, participatory activities and surveys have been used (O' Kane 2008: 129). Focus group discussions were used as the primary research methodology because of its power of communication as it enabled children and young people to talk about the sorts of issues that affect them and how these issues lead to lack of peace and development in society.

This study involved listening to the views and opinions of 47 children (23 girls and 24 boys) aged between 8-17 years, who were drawn from the 47 counties of the country. In essence this was a National Children's Assembly that included the President, Deputy President, Cabinet Secretaries, the National Speaker, Clerk and county Delegates. . Therefore, the children reflected the cultural diversity, and the urban, semi-urban and rural mix. The researcher, through the Children's officer, informed the children the purpose of the interview and how the information would be used. This was in line with the ethical principles in undertaking a child participation initiative as described by Hart (1992:8). It requires that the child be adequately informed about his/her role in the participation of the research.

The research took place in mid-November, 2011 at the Railways Club, Nairobi where children had converged for the annual forum which was marking its $10^{\text {th }}$ year. The theme for the year was "Reading for Fun". The interview questions followed a brief explanation of the role of the of the Children's Assembly in Kenya before embarking on the discussion of other issues that affect children from different places of the country. The details of the discussions and the views of children are presented below.

\section{Interviewer: So what is the role of the Children's Assembly in Kenya?}

Speaker (aged 13): We as children gather every year to discuss and come up with solutions to various issues that affect us as children and also those that touch on our rights. These include rights to education, shelter, association among other issues. During such meetings our organizers make sure that all the 47 counties in the country are represented. 
you say that the assembly has benefited the Kenyan child?

Speaker: (Peter aged 16) I would say that it has made a positive impact since many children now know their rights. For example as far as the rights to education are concerned, I can say that at the moment there are many children going to school. But we know that there are some children who are not going to school in some areas. We get this Information from the county representatives during our meetings such as this one. In a sense I can say that children in Kenya will no longer be looked at as passive recipients of decision making about their lives.

Interviewer: So, in situations where children do not go to school, how does the assembly help such children?

Speaker: During our last meeting, we agreed that we should write letters to our members of parliament to help us have these children go to school. By the end of this session we will know how many of us wrote the letters.

Interviewer: Tell me about today's meeting.

Speaker: As you can see from there (pointing to the Billboard) the theme of the Conference is "Reading for Fun".

Interviewer: Tell me about it.

Speaker: This time we wanted to encourage the children to read. We have noted that many children read to pass exams and few read for leisure. Like today we are organized into small groups to discuss various issues regarding the theme of today. Later we came together and presented our findings. The findings will be given to the children Officers to forward them to various schools for action.

Interviewer: Now, tell me about your group. What issues were discussed? We can also freely listen to views from other members.

Speaker: In my group we discussed about things that prevent children from developing an interest in reading.

Interviewer: Tell me about these issues.

Speaker: One member in my group, who is from the nomadic group said that in his community, people keep moving from one place to another with their families in search of pasture and sometimes they don't carry the books with them.

Ohana (a girl aged 14): In my group we noted that lack of libraries in slum areas and other settlement areas is a big setback on the reading culture among children living in these areas.

Interviewer: What were some of the solutions suggested by your groups?

Speaker: We requested the government to provide these children with books so that they can carry with them and read them as they look after their cows. We also proposed that mobile libraries be made available in such areas.

Ohana: We proposed that we write letters to big organizations and the big people in society to donate books to schools in slum areas.

Wafula (a boy, aged 15): In our group we suggested that parents should spare some money and buy us books. For example when they go to shop, they can be buying one book then we share the books even with our neighbors. 
Nyambura (a girl, aged 16): The problem is that we do not have time for extra reading, especially for us children from the rural areas. This is because after school we are engaged in a lot of housework. We are only left with little time to do homework so we cannot even think about reading storybooks.

Chebet (a girl, aged 15): We suggested that the government should build children friendly libraries in all counties.

Wambugu (a boy aged 15) had this to say regarding education. "In Laikipia county, some children did not go to school because their parents worked in ranches and that only a few ranches had schools and therefore majority of children did not attend school due to lack of availability of schools. For those children who were in school, the schools are miles away from home and therefore the children have to walk long distances. In such a case, then the young children cannot also attend school. Again in my county one finds a big number of children who have dropped out of school, some in primary and others in secondary schools most of them have joined their parents to work in the ranches leading to cases of child labor."

Waithera (a girl aged 14) representing Kirinyaga County, pointed out three major issues she wanted to see addressed. "I would like to see the following issues addressed because they affect in a big way most of the children I represent. One of the issues is the rights of the girl -child. The girls in my county continue to suffer educational disadvantage in terms of lower access, and are always being told to repeat classes because of poor performance.

Interviewer: What other issues were discussed other than the need to develop a reading culture among the children?

Jacob (a boy aged 16), reported that his group discussed the issue of orphaned and disadvantaged children. He observed that some children from his county did not attend school in the first place. She pointed out that these children were forced into child labor. She said "It moves my heart when I walk the streets and see destitute children who are supposed to be in school suffering with no one to take care of them. My heart bleeds when I see them being harassed. It pains me when some parents refuse to educate their children and instead force them into child labor."

Speaker of the Assembly: Now days you cannot miss to meet a street child even in the small towns. I think the problem has become so big. We only wish that the government can build homes for these children so that they can be taken care of.

Interviewer: What do you think should be done?

Rose (A girl aged 12): One, the government can build good homes for the children so that they are all taken there.

Ambasa (a boy aged 13): I think families can be encouraged to adopt these children. In my county, one of the leaders told me that The CDF committee (the Constituency Development Fund) gives some money to those parents who are fostering orphaned children. Maybe other counties can also learn from my county.

Interviewer: Tell me more about other issues that you discussed.

Wambulwa (A boy aged 12): Let me talk about the disabled children from my Kakamega county. As you can see I am physically disabled but this, as I tell other children is not reason for me not to work hard in school. My parents support me very much. But there are children who do not go to school because, one, their friends laugh at their disabilities and two, their parents don't support them. For some they are so disabled such that they can not move without the support of machines. Their parents cannot afford to buy the machines for them. I have pledged for the construction of more public physiotherapy 
clinics, counseling centers and schools for children with disabilities. He also noted that, "Most physiotherapy clinics and schools for children with disabilities are privately owned and most parents cannot afford their services. This denies disabled children from poor families education and physiotherapy services that is necessary for the well-being."

Waithera (a girl aged 14) representing Kirinyaga County, pointed out the following "I would like to see the following issues addressed because they affect in a big way most of the children I represent. One of the issues is the rights of the girl -child. The girls in my county continued to suffer educational disadvantage in terms of lower access and repetition. For those who are forced to repeat, some decide to drop out of school. For the rest, by the time they finish class eight, they feel so old and some are called names like granny. So they opt not to continue with education.

Deputy Speaker (a girl, aged 14): There is the issue of abuse such as corporal punishment in school and even at home. The children are beaten by their parents and teachers, some to the point of death. We would like this to stop. Our teachers and parents are hurting us.

\section{Findings and Discussions}

From the discussions held with children from different counties, it can be concluded that children live under incredibly challenging circumstances and as a result they need to come out and speak out about their problems in their own ways. It has been observed from the study that children in Kenya would like to see a range of issues that affect them addressed.

From such statements from the children's representatives, it can be deduced that children are now being seen as potentially having views and ideas about their own lives and of having a right to genuine participation in decision making affecting their lives. This is in line with Article 12 of the UN Convention on the Rights of the Child, which imposes on states duties to assure to children the right to express views on all matters which affect them.

The social-cultural practices such as female genital mutilation (FGM) and other rites of passage as well as early marriages and teenage pregnancies cause girls to drop out of school. These were also some of the issues raised by the Governor from Garissa County (Halima aged 15) where cultural activities such as female circumcisions are still practiced. Once a girl has been circumcised, she is considered old enough by the community to be married and start her own home, thus curtailing her education completely. It can be observed from these views that children are seen as active agents making appeals concerning educational provisions on behalf of their colleagues who cannot access reading materials due to the various difficult situations that affect them.

The problem of orphaned children and the street children is still an issue that has not been completely tackled by the government. In addition, child labor still thrives in many families, despite the fact that these children are supposed to be in school. Due to policies such as elimination of school fees, the primary education sub-sector has so far experienced a very fast growth of enrolment. However, marginalized children seem to be at a disadvantage as observed by the children.

Abuse is here seen in terms of physical, emotional and sexual abuse and neglect. As observed by Taylor (2009: 31) abuse can be linked more closely to rights; that is be interpreted as any act of omission or commission by individuals, institutions or society as a whole which prevents the child from reaching their potential or denies them equal rights. In deed the government of Kenya through the Ministry of Education prohibits corporal punishment in school. Although this is the case, there are many incidences of corporal punishment that have been reported either in some schools and even some homes. In addition, she observed that there were many cases of defilement in her county and she wanted parents and the various authorities to come out and protect their children.

The issues discussed by the children's representatives range from accessibility to education, child labor, 
children with disabilities, orphans and abolition of corporal punishment at home and school. In some cases, the children have provided suggestions regarding the action that should be taken by the stakeholders in addressing these issues. The above issues raised by children shows the need to support children in order for the children to contribute towards peace thus leading to a peaceful society.

\section{Conclusions}

The concept of children's agency has been used in various ways by the children themselves considering that every day of their lives emphasizes their capacities as experiencing subjects capable of autonomous actions. When children are given a platform for participation, there is a greater responsibility that accompanies it. If the children seize these forum and understand the values their voices brings, they can increase their own learning and develop leadership abilities. These abilities will enable them to be agents of peace in their respective communities, by analyzing problems critically, acting as agents of peace and finally fostering harmonious and cooperative relations among people. In addition, through this platform, children expose themselves to new and creative ideas that will be of service to their families, community, nation and potentially the world. Finally, children's involvement in debate constitutes an important area for social democratization that can lead to peace in the society.

\section{References}

Boyden, J. \& Ennew, J. (1997). Children in Focus- a manual for Participatory Research with Children, Rädda Barnen, Stockholm.

Ehlers, L \& Frank C. (2008). "Child Participation in Africa." In: Nielsen J.S. (ed) Children's Rights in Africa: A legal Perspective. Ashgate Publishing House. England. 111-127.

Hart, R. (1992). "Children's Participation: from tokenism to citizenship". Innocenti Essay, No 4, UNICEF, Rome.

Honwana A. (2005). "Innocent and Guilty: Child Soldiers as Interstitial and Tactical Agents." In: Honwana A. \& De Boek, F. (Eds.) Markers \& Breakers: Children and Youth in Post-Colonial Africa. James Carey Ltd. Oxford. 31-52.

James A. \& Prout A. (1997). "Introduction: Constructing and Reconstruction Childhood." In James A. \& Alan Prout (eds). Constructing and Reconstruction Childhood. Routledge. New York.1- 6

Jans, M. (2004). “Children as Citizens: Towards a Contemporary Notion of Child Participation”. In: Childhood: A Global Journal of Child Research. Vol. II No. 1 February 2004. 27 - 44.

Kenya National Assembly Official Record (Hansard) (2001). Children's Bill 2001. Government of Kenya.

Lansdown, G. (2005). The Evolving Capacities of the Child. Florence. Innocenti Research Centre, UNICEF

McNeil, S. (1998). "Child Participation: ethical values and the impact of mass media". In: Johnson, et al (Eds). Stepping Forward: Children and Young people's Participation in the Development Process. Intermediate Technology Publications. London. 31- 33.

Mokwana, S. (2003). "Youth Participation: taking the idea to the next level: a challenge to youth ministers." In: Commonwealth Youth and Development. Vol.1. No. 2. 87- 107.

Mukasa, G. \& Van Der Grift-Wanyoto, V. (1998). "Giving Children Voices". In: Johnson, et al (Eds). Stepping Forward: Children and Young people's Participation in the Development Process. Intermediate Technology Publications. London. 278- 280.

Ofosi-Kusi, Y. (2011). 'Children's Agency and Development in African Societies'. Introductory Lecture delivered at the 2011 Child and Youth Studies Institute, CODESRIA, Dakar, Senegal. 
Republic of Kenya (2010). The Constitution of Kenya. Nairobi. Government Printers.

Smith E.I. (1998). "Introduction to Children's Participation. In: Johnson et al (Eds). Stepping Forward: Children and Young people's Participation in the Development Process. Intermediate Technology Publications. London. 259 -262.

Taylor A.S. (2009). “The UN Convention on the Rights of the Child: giving children a Voice." In: A. Lewis and Lindsay (eds) Researching Children's Perspectives. Open University Press, Berkshire. 21- 33

Theis, J. (1998). "Participatory Research on Child Labor in Vietnam.” In: Johnson et al (Eds). Stepping Forward: Children and Young people's Participation in the Development Process. Intermediate Technology Publications. London. 81-85.

White, S. C. \& Choudhury, S. A. (2010). "Children's Participation in Bangladesh: Issues of Agency and Structure of Violence." In: A Handbook of Children and Young Peoples Participation Perspectives from Theory and Practice.

\section{About the Author}

Dr. Pamela Ngugi is a senior lecturer in the Department of Kiswahili and African Languages, Kenyatta University, Kenya. 